\title{
Polychaete fauna associated with holdfasts of the large brown alga Himantothallus grandifolius in Admiralty Bay, King George Island, Antarctic
}

\author{
Krzysztof Pabis $\cdot$ Jacek Sicinski
}

Received: 8 January 2010/Revised: 31 March 2010/ Accepted: 30 April 2010/Published online: 22 May 2010

(C) The Author(s) 2010. This article is published with open access at Springerlink.com

\begin{abstract}
The polychaete community associated with holdfasts of the brown alga Himantothallus grandifolius in Admiralty Bay has been studied. It is the first study of its kind in this area and only the second in the Antarctic. Samples were collected in the summer season of 1979/ 1980 from a depth range of 10-75 m. Seventy-eight species were found on 19 holdfasts. The community was dominated by Brania rhopalophora and Neanthes kerguelensis. Analysis of similarity showed that polychaete fauna associated with this habitat did not show any partitioning related to depth. Regression analysis showed that densities of both species and individuals decreased with increased holdfast volume. A positive correlation was found between the number of individuals and holdfast volume. Polychaetes from 10 feeding guilds were found with dominance of macrophagous motile herbivores and sessile filter feeders. The complex habitat provided by holdfasts is a shelter for a rich polychaete fauna and may function as important protection from disturbance in the shallow areas of Admiralty Bay.
\end{abstract}

Keywords West Antarctic - Holdfast fauna . Habitat heterogeneity · Habitat complexity · Polychaete

K. Pabis $(\bowtie) \cdot$ J. Sicinski

Laboratory of Polar Biology and Oceanobiology,

University of Lodz, Banacha 12/16, 90-237 Lodz, Poland

e-mail: cataclysta@wp.pl

J. Sicinski

e-mail: sicinski@biol.uni.lodz.pl

\section{Introduction}

Thalli and holdfasts of large brown algae are considered to be structurally complex habitats (Steneck et al. 2002). The degree of habitat complexity is an effect of increasing effective surface area or volume available for various organisms (Le Hir and Hily 2005). It has already been pointed out that complex habitats support a more diverse fauna and species richness in those habitats is high (Kohn and Leviten 1976; Smith 2000; Norderhaug et al. 2002; Anderson et al. 2005; Eriksson et al. 2006; Coleman et al. 2007). There are a few reasons for increased diversity in these habitats. These, mostly biogenic, structures can provide a shelter for invertebrates and decrease the influence of mechanical stress (Koehl 1999; Smith 2000). Competition and the influence of predators could be lower in these habitats (Almany 2004; Corkum and Cronin 2004; Hereu et al. 2005). Also, the number of potential ecological niches and diverse ways of exploiting the environmental resources could be higher in these habitats (Tews et al. 2004). It was recently emphasized that Southern Ocean benthic communities have as yet rarely been analysed in the context of structural heterogeneity of habitats. This lack of such research is particularly distinct in macroalgal forests, which are the most important complex biodiversity hot spots in the Antarctic (Gray 2001).

There are only scarce data reported on Antarctic and Subantarctic invertebrate faunas associated with holdfasts of various macroalgae and most of these contain only species lists with minor ecological interpretation or are based on the composition of higher taxa. Arnaud (1974) presented some information on the invertebrate fauna of Macrocystis pyrifera (L.) C. Agardh and Durvillea antarctica (Chamisso) Hariot holdfasts from Morbihan Bay on the Kerguelen Islands and of Himantothallus grandifolius (A. Gepp \& E.S. 
Gepp) Zinova holdfasts from Adélie Land. A short list of species found on floating Macrocystis pyrifera rhizoids from the Subantarctic and the Patagonian shelf was presented by Smirnov (1982). Invertebrate communities associated with Durvillea antarctica holdfasts from the Subantarctic Macquarie Island were also recently described by Smith and Simpson $(1998,2002)$. Benthic macroinvertebrate communities associated with Macrocystis pyrifera have also been analysed in Southern Chile (Ojeda and Santelices 1984), the Strait of Magellan (Rios et al. 2007) and in the Beagle Channel (Adami and Gordillo 1999).

Current knowledge on holdfast macroinvertebrate faunas in Antarctica is poor. Recognition of holdfast fauna can be also a first step in understanding the patterns of distribution of some species in the Antarctic. Detached thalli and holdfasts drifting with Antarctic Circumpolar Current may be an important vector for dispersion and the reason for the circumpolar distribution of many invertebrates including polychaetes (Edgar 1987; Helmuth et al. 1994; Smith 2002).

Polychaete diversity and distribution have been intensively studied in Admiralty Bay, but all the studies were focused on the soft-bottom fauna (Sicinski 1986; Sicinski and Janowska 1993; Bromberg et al. 2000; Sicinski 2004; Petti et al. 2006; Pabis and Sicinski 2010). In Admiralty Bay, the phytal zone covers about $30 \%$ of the bottom surface and until now there are no data on macroinvertebrate communities associated with this habitat. The most dense and diverse algal communities are located in the central basin. Among 42 taxa of seaweeds recorded from this basin H. grandifolius and Desmarestia anceps Montagne are among the most common species and have the highest range of vertical distribution. Both species can be found from 10 to $90 \mathrm{~m}$ depth (Furmanczyk and Zielinski 1982; Zielinski 1990; Oliveira et al. 2009). Holdfasts of the large brown alga $H$. grandifolius are attached to dropstones, which are the only hard substratum on the soft bottom and can be treated as small islands on the surrounding soft bottom. As a result, $H$. grandifolius differs from most of the other species of large Antarctic brown algae, which are associated with typical hard bottoms. The three-dimensional labyrinth of holdfasts (Fig. 1) forms a very peculiar, complex habitat compared to compacted, shallow sublittoral bottom sediments. The aim of the present study was to describe the polychaete community associated with holdfasts of H. grandifolius in Admiralty Bay.

\section{Materials and methods}

Study area

Admiralty Bay is a fjord-like embayment, which consists of a central basin and three inlets: Ezcurra Inlet, Martel

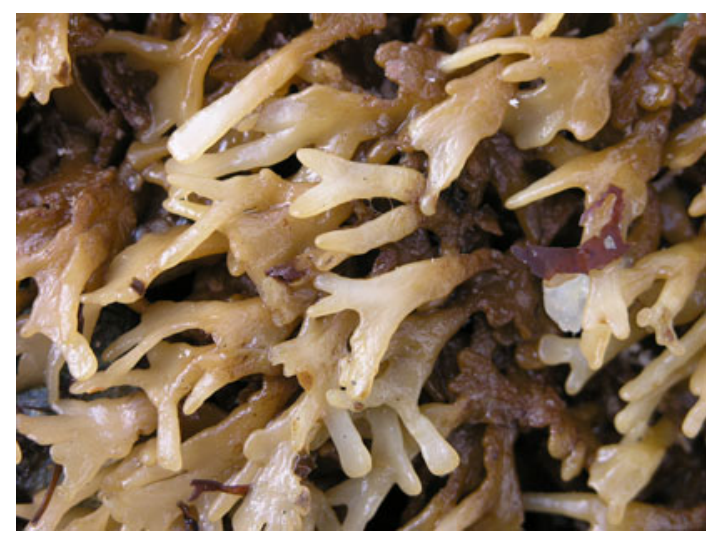

Fig. 1 Holdfast of Himantothallus grandifolius

Inlet and MacKellar Inlet. The central basin is the deepest part of the bay, reaching $550 \mathrm{~m}$, and it is open to the Bransfield Strait. Almost half of the Admiralty Bay shoreline is covered by glaciers and icefalls especially on the eastern coast of the central basin and in the inner fjords (Braun and Grossmann 2002). It is the largest bay on the South Shetland Islands with surface area of approximately $120 \mathrm{~km}^{2}$.

A large part of the Admiralty Bay coastline has a surrounding macroalgal zone (Oliveira et al. 2009). The most dense macroalgal populations are distributed in the central basin of the bay and the poorest in the Ezcurra Inlet. The total macroalgal biomass of Admiralty Bay was estimated to be around 74,000 tonnes (Furmanczyk and Zielinski 1982; Zielinski 1990).

\section{Sampling}

Material was collected in the central basin of Admiralty Bay close to the "H. Arctowski" Polish Station (Fig. 2). Nineteen $H$. grandifolius holdfasts from a depth range of 10-75 m were collected in the summer season of 1979/ 1980. The volume of each holdfast was measured by placing it in a beaker and measuring the volume of displaced water. Holdfasts were pulled off the bottom together with whole thalli that were attached to various sampling gears such as bottom nets, fish pots or dredges (net mesh size from 0.1 to $0.5 \mathrm{~cm}$ ). In the laboratory, the holdfasts were washed over a $0.5 \mathrm{~mm}$ sieve. On board the ship, each holdfast was carefully put into a separate container immediately after the sample was brought on board. Only the holdfasts that were still partially filled with sediment and still attached to a dropstone, and thus in which the invertebrates had not been washed out by water, were used. Thus, possible underestimations, which may result from invertebrates that could actively escape were minimized and may concern rather amphipods than (even motile) polychaetes. 


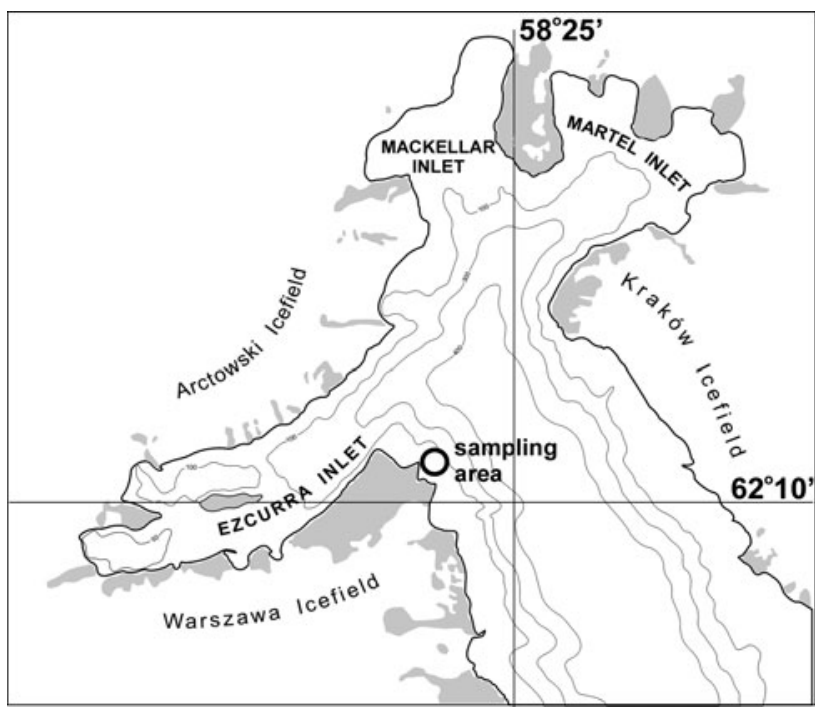

Fig. 2 Admiralty Bay with the indicated sampling area

In the polar conditions, it is very difficult to collect such material from the deeper sublittoral by SCUBA diving. This is why previous similar analyses were restricted to very shallow (several meters) depths (Arnaud 1974; Dunton et al. 1982; Wlodarska-Kowalczuk et al. 2009). The present study involves sampling from depths that are out of the range of SCUBA diving in the Antarctic (up to $75 \mathrm{~m}$ depth).

\section{Data analysis}

Similarity analyses between samples based on the Bray-Curtis similarity coefficient were performed using the PRIMER Package (Clarke and Warwick 1994). As non-comparable samples (holdfasts of different volume) were used in the analysis, standardization of data was applied. In each sample, the number of individuals of each species was divided by the total abundance (number of individuals) of all species in a given sample, the procedure recommended for samples of different volume or surface area by Clarke and Warwick (1994). Sample counts were then square root transformed. Hierarchical agglomerative clustering was performed using the group average method.

Number of species, species density [spec./100 ml] and total density of individuals [ind./100 ml] were measured for each sample. The relationships between the holdfast volume and density of individuals, species density and number of species of polychaetes, as well as between holdfast volume and number of individuals, were examined using regression analyses. Regression analysis was also used to examine the relationship between the sample depth and the density of individuals. The frequency of occurrence, dominance and density [ind./100 ml] of each species
Table 1 Holdfast samples list together with information on volume of each holdfast, depth and number of species and number of individuals

\begin{tabular}{llllc}
\hline Sample & $\begin{array}{l}\text { Depth } \\
{[\mathrm{m}]}\end{array}$ & $\begin{array}{l}\text { Holdfast } \\
\text { volume }(\mathrm{ml})\end{array}$ & $\begin{array}{l}\text { Number of } \\
\text { species }\end{array}$ & $\begin{array}{l}\text { Number of } \\
\text { individuals }\end{array}$ \\
\hline A1 & 10 & 500 & 16 & 440 \\
A2 & 11 & 720 & 17 & 497 \\
A3 & 11 & 940 & 19 & 567 \\
A4 & 13 & 590 & 13 & 93 \\
A5 & 15 & 190 & 22 & 161 \\
A6 & 15 & 100 & 28 & 133 \\
A7 & 15 & 220 & 21 & 73 \\
A8 & 20 & 60 & 14 & 158 \\
A9 & 23 & 310 & 13 & 137 \\
A10 & 30 & 100 & 11 & 58 \\
A11 & 30 & 290 & 23 & 205 \\
A12 & 30 & 140 & 26 & 101 \\
A13 & 30 & 380 & 23 & 198 \\
A14 & 30 & 640 & 24 & 252 \\
A15 & 45 & 360 & 19 & 109 \\
A16 & 45 & 350 & 19 & 110 \\
A17 & 75 & 500 & 35 & 132 \\
A18 & 75 & 680 & 11 & 144 \\
A19 & 75 & 360 & 27 & 133 \\
\hline
\end{tabular}

was calculated. Each species was also assigned to a feeding guild according to the classification proposed by Fauchald and Jumars (1979).

\section{Results}

Seventy-eight species of polychaetes were found on 19 H. grandifolius holdfasts (3701 individuals). The volume of the holdfasts varied between 60 and $940 \mathrm{ml}$. The number of species found on a single holdfast ranged between 11 and 35 (Table 1). Some Spirorbidae other than Paralaeospira antarctica and Spirorbidae gen sp. was not identified to the species level owing to the poor condition of the material (Table 2). In the cluster analysis, the polychaete fauna constituted one group at $40 \%$ similarity, and there was no depth or holdfast-volume partitioning observed (Fig. 3). This polychaete community seems to be very uniform in its nature at least in the composition of its dominant species and in the dominance structure. The most frequent and dominant species were Brania rhopalophora $(D=23.3 \%, \quad F=94.7 \%)$ and Neanthes kerguelensis $(D=21.3 \%, F=100.0 \%)$. Other important species were Rhodine intermedia $(D=6.9 \%$, $F=89.5 \%)$, Oriopsis alata $(D=4.7 \%, F=68.4 \%)$, Exogone heterosetosa $(D=4.5 \%, F=84.2 \%)$, Scoloplos 
Table 2 Dominance $(D)$, frequency of occurrence $(F)$ and density [ind./100 ml] of polychaetes together with its feeding guild (Fauchald and Jumars 1979)

\begin{tabular}{|c|c|c|c|c|c|}
\hline \multirow{2}{*}{$\begin{array}{l}\text { Species } \\
\text { Barrukia cristata (Willey, 1902) }\end{array}$} & \multirow{2}{*}{$\begin{array}{l}\text { Feeding guild } \\
\text { CMJ }\end{array}$} & \multirow{2}{*}{$\frac{D[\%]}{0.05}$} & \multirow{2}{*}{$\begin{array}{r}F[\%] \\
10.5\end{array}$} & \multicolumn{2}{|c|}{$\begin{array}{l}\text { Mean density } \\
\text { [ind./100 ml] with SD }\end{array}$} \\
\hline & & & & 0.02 & 0.09 \\
\hline Harmothoe sp. & $\mathrm{CMJ}$ & 0.5 & 52.6 & 0.5 & 0.7 \\
\hline Pholoe sp. & $\mathrm{CMJ}$ & 0.02 & 5.3 & 0.01 & 0.04 \\
\hline Sigalionidae gen. sp. & $\mathrm{CMJ}$ & 0.08 & 15.8 & 0.06 & 0.2 \\
\hline Euphrosine armadilloides Ehlers, 1900 & $\mathrm{CMJ}$ & 0.02 & 5.3 & 0.01 & 0.04 \\
\hline Anaitides patagonica (Kinberg, 1866) & $\mathrm{CMJ}$ & 0.05 & 5.3 & 0.02 & 0.1 \\
\hline Eteone sculpta Ehlers, 1897 & $\mathrm{CMJ}$ & 0.08 & 10.5 & 0.04 & 0.1 \\
\hline Genetyllis polyphylla (Ehlers, 1897) & $\mathrm{CMJ}$ & 0.9 & 26.3 & 0.5 & 1.4 \\
\hline Eulalia picta (Kinberg, 1866) & $\mathrm{CMJ}$ & 0.4 & 31.6 & 0.4 & 0.8 \\
\hline Phyllodocidae gen. sp. 1 & $\mathrm{CMJ}$ & 0.2 & 15.8 & 0.1 & 0.4 \\
\hline Phyllodocidae gen. sp. 2 & $\mathrm{CMJ}$ & 0.6 & 42.1 & 0.3 & 0.4 \\
\hline Phyllodocidae gen. sp. 3 & $\mathrm{CMJ}$ & 0.1 & 15.8 & 0.05 & 0.1 \\
\hline Brania rhopalophora (Ehlers, 1897) & HMJ & 23.3 & 94.7 & 16.8 & 29.4 \\
\hline $\begin{array}{l}\text { Exogone heterosetoides australis Hartmann- } \\
\text { Schröder \& Rosenfeldt, } 1988\end{array}$ & HMJ & 1.0 & 42.1 & 0.9 & 2.2 \\
\hline Exogone heterosetosa McIntosh, 1885 & HMJ & 4.5 & 84.2 & 3.7 & 4.9 \\
\hline Exogone tridentata Hartmann-Schröder and Rosenfeldt, 1993 & HMJ & 0.05 & 5.3 & 0.1 & 0.4 \\
\hline Eusyllis maxima (Monro, 1930) & $\mathrm{CMJ}$ & 0.02 & 5.3 & 0.005 & 0.02 \\
\hline Syllides articulosus Ehlers, 1897 & $\mathrm{CMJ}$ & 0.05 & 10.5 & 0.03 & 0.1 \\
\hline Typosyllis sp. & $\mathrm{CMJ}$ & 0.02 & 5.3 & 0.01 & 0.04 \\
\hline Exogoninae gen. sp. & HMJ & 0.9 & 42.1 & 0.8 & 1.5 \\
\hline Syllidae gen. sp. 1 & $\mathrm{CMJ}$ & 0.02 & 5.3 & 0.005 & 0.02 \\
\hline Syllidae gen. sp. 2 & $\mathrm{CMJ}$ & 0.05 & 5.3 & 0.02 & 0.1 \\
\hline Hesionidae gen. sp. & $\mathrm{CMJ}$ & 0.2 & 21.0 & 0.08 & 0.2 \\
\hline Neanthes kerguelensis (McIntosh, 1885) & HMJ & 21.3 & 100.0 & 11.0 & 11.2 \\
\hline Micronereis sp. & HMJ & 0.02 & 5.3 & 0.02 & 0.09 \\
\hline Aglaophamus trissophyllus (Grube, 1877) & $\mathrm{CMJ}$ & 0.05 & 10.5 & 0.03 & 0.1 \\
\hline Sphaerodoropsis parva (Ehlers, 1913) & BMX & 0.3 & 42.1 & 0.1 & 0.3 \\
\hline Glycera kerguelensis McIntosh, 1885 & CDJ & 0.02 & 5.3 & 0.01 & 0.04 \\
\hline Lumbrineris magalhaensis (Kinberg, 1865) & CDJ & 3.3 & 78.9 & 3.0 & 5.9 \\
\hline Dorvilleidae gen. sp. & HMJ & 0.02 & 5.3 & 0.05 & 0.2 \\
\hline Ophryotrocha notialis (Ehlers, 1908) & HMJ & 0.4 & 26.3 & 0.3 & 0.9 \\
\hline Leitoscoloplos kerguelensis (McIntosh, 1885) & BMX & 1.6 & 57.9 & 1.3 & 2.3 \\
\hline Orbinia (P.) minima Hartmann-Schröder \& Rosenfeldt, 1990 & BMX & 0.02 & 5.3 & 0.01 & 0.07 \\
\hline Scoloplos (L.) marginatus (Ehlers, 1897) & BMX & 3.4 & 84.2 & 1.4 & 1.1 \\
\hline Scoloplos (S.) sp. & BMX & 0.1 & 5.3 & 0.04 & 0.2 \\
\hline Aricidea (A.) antarctica Hartmann-Schröder and Rosenfeldt, 1988 & SMX & 0.08 & 5.3 & 0.02 & 0.1 \\
\hline Cirrophorus brevicirratus Strelzov, 1973 & SMX & 0.4 & 21.0 & 0.2 & 0.8 \\
\hline Microspio moorei (Gravier, 1911) & SDT & 0.02 & 5.3 & 0.01 & 0.07 \\
\hline Spiophanes tcherniai Fauvel, 1950 & SDT & 0.7 & 42.1 & 0.5 & 1.1 \\
\hline Apistobranchus glacierae Hartman, 1978 & SDT & 0.4 & 31.6 & 0.3 & 0.5 \\
\hline Caulleriella sp. & SMT & 0.08 & 10.5 & 0.1 & 0.4 \\
\hline Cirriformia sp & SMT & 0.6 & 15.8 & 0.4 & 1.09 \\
\hline Tharyx cincinnatus (Ehlers, 1908) & SMT & 1.2 & 31.6 & 0.3 & 1.0 \\
\hline Tharyx epitoca Monro, 1930 & SMT & 2.0 & 21.0 & 1.3 & 4.2 \\
\hline Tharyx sp. & SMT & 0.1 & 15.8 & 0.06 & 0.1 \\
\hline
\end{tabular}


Table 2 continued

\begin{tabular}{|c|c|c|c|c|c|}
\hline \multirow{2}{*}{$\begin{array}{l}\text { Species } \\
\text { Cirratulidae gen. sp. } 1\end{array}$} & \multirow{2}{*}{$\begin{array}{l}\text { Feeding guild } \\
\text { SMT }\end{array}$} & \multirow{2}{*}{$\frac{D[\%]}{2.1}$} & \multirow{2}{*}{$\begin{array}{r}F[\%] \\
52.6\end{array}$} & \multicolumn{2}{|c|}{$\begin{array}{l}\text { Mean density } \\
\text { [ind./100 ml] with SD }\end{array}$} \\
\hline & & & & 1.2 & 1.8 \\
\hline Cirratulidae gen. sp. 2 & SMT & 0.02 & 5.3 & 0.01 & 0.07 \\
\hline Flabelligera mundata Gravier, 1907 & SDT & 0.08 & 5.3 & 0.03 & 0.1 \\
\hline Flabelligera sp. & SDT & 0.02 & 5.3 & 0.01 & 0.07 \\
\hline Sclerocheilus antarcticus Ashworth, 1915 & BMX & 0.05 & 10.5 & 0.02 & 0.08 \\
\hline Ophelina syringopyge (Ehlers, 1901) & BMX & 0.1 & 15.8 & 0.05 & 0.1 \\
\hline Capitella sp. & BMX & 1.9 & 89.5 & 1.7 & 3.4 \\
\hline $\begin{array}{l}\text { Eupraxillella antarctica Hartmann-Schröder } \\
\text { and Rosenfeldt, } 1989\end{array}$ & BSX & 0.3 & 31.6 & 0.2 & 0.5 \\
\hline Lumbriclymenella robusta Arwidsson, 1911 & BSX & 0.7 & 21.0 & 0.7 & 2.9 \\
\hline Rhodine intermedia Arwidsson, 1911 & BSX & 6.9 & 89.5 & 3.5 & 2.2 \\
\hline Ampharete kerguelensis McIntosh, 1885 & SST & 0.02 & 5.3 & 0.03 & 0.1 \\
\hline Ampharetinae gen. sp. & SST & 0.02 & 5.3 & 0.03 & 0.1 \\
\hline Amphitrite kerguelensis McIntosh, 1876 & SST & 0.05 & 10.5 & 0.04 & 0.1 \\
\hline Nicolea sp. & SDT & 0.02 & 5.3 & 0.02 & 0.1 \\
\hline Pista patriciae Hartmann-Schröder and Rosenfeldt, 1989 & SST & 0.02 & 5.3 & 0.01 & 0.04 \\
\hline Polycirrus kerguelensis (McIntosh, 1885) & SDT & 2.0 & 78.9 & 1.5 & 2.2 \\
\hline Polycirrus insignis Gravier, 1907 & SDT & 2.0 & 57.9 & 1.2 & 2.2 \\
\hline Proclea sp. & SST & 0.05 & 10.5 & 0.09 & 0.3 \\
\hline Thelepus cincinnatus (Fabricius, 1780) & SST & 0.1 & 10.5 & 0.06 & 0.2 \\
\hline Amphitritinae gen. sp. & SST & 0.08 & 10.5 & 0.1 & 0.4 \\
\hline Terebellides kerguelensis (McIntosh, 1885) & SST & 0.02 & 5.3 & 0.01 & 0.04 \\
\hline Trichobranchus glacialis antarcticus Hessle, 1917 & SST & 0.4 & 36.8 & 0.3 & 0.5 \\
\hline Trichobranchus sp. & SST & 0.2 & 5.3 & 0.2 & 0.9 \\
\hline Euchone pallida Ehlers, 1908 & FST & 0.01 & 5.3 & 0.01 & 0.06 \\
\hline Oriopsis alata (Ehlers, 1897) & FST & 4.7 & 68.4 & 1.7 & 2.4 \\
\hline $\begin{array}{l}\text { Oriopsis kocki Hartmann-Schröder and Rosenfeldt, } \\
1989\end{array}$ & FST & 0.5 & 10.5 & 1.0 & 4.1 \\
\hline $\begin{array}{l}\text { Oriopsis longipyge Hartmann-Schröder and Rosenfeldt, } \\
1989\end{array}$ & FST & 0.3 & 26.3 & 0.3 & 0.8 \\
\hline Oriopsis sp. & FST & 0.5 & 36.8 & 0.5 & 1.4 \\
\hline Perkinsiana littoralis (Hartman, 1967) & FST & 0.05 & 5.3 & 0.02 & 0.09 \\
\hline Sabellinae gen. sp. 1 & FST & 0.02 & 5.3 & 0.01 & 0.04 \\
\hline Sabellinae gen. sp. 2 & FST & 0.02 & 5.3 & 0.01 & 0.04 \\
\hline Paralaeospira antarctica (Pixell, 1913) & FST & 5.3 & 15.8 & 2.0 & 7.0 \\
\hline Spirorbidae gen. sp. & FST & 0.1 & 5.3 & 0.05 & 0.2 \\
\hline Spirorbidae non det. & FST & 1.5 & 63.1 & 1.8 & 3.4 \\
\hline
\end{tabular}

CMJ carnivore, motile, jawed; $H M J$ herbivore, motile, jawed; $B M X$ burrowing, motile, non-jawed; $C D J$ carnivore, discretely motile, jawed; $S M X$ surface deposit feeding, motile, non-jawed; $S D T$ surface deposit feeding, discretely motile, tentaculate; SMT surface deposit feeding, motile, tentaculate; $B S X$ burrowing, sessile, non-jawed; $S S T$ surface deposit feeding, sessile, tentaculate; FST filter feeding, sessile, tentaculate

marginatus $(D=3.4 \%, F=84.2 \%)$ and Lumbrineris magalhaensis $(D=3.3 \%, \quad F=78.9 \%)$. Other less numerous but still quite frequent species were Capitella sp. $(D=1.9 \%, \quad F=89,5 \%)$, Polycirrus kerguelensis $(D=2.0 \%, F=78.9 \%)$, Polycirrus insignis $(D=2.0 \%$, $F=57.9 \%)$ and Cirratulidae gen. sp. $1(D=2.1 \%, F=$ $52.6 \%$ ). A further dominant species was Paralaeospira antarctica, but the frequency value for this species was low $(D=5.3 \%, F=15.8 \%)$.

The highest mean densities were found for B. rhopalophora (16.9 ind./100 ml) and N. kerguelensis (11.0 ind./ $100 \mathrm{ml}$ ). For other species, mean densities were low and did not exceed 4 ind./100 $\mathrm{ml}$, for most of the species being much lower than 1 ind./100 $\mathrm{ml}$ (Table 2). 


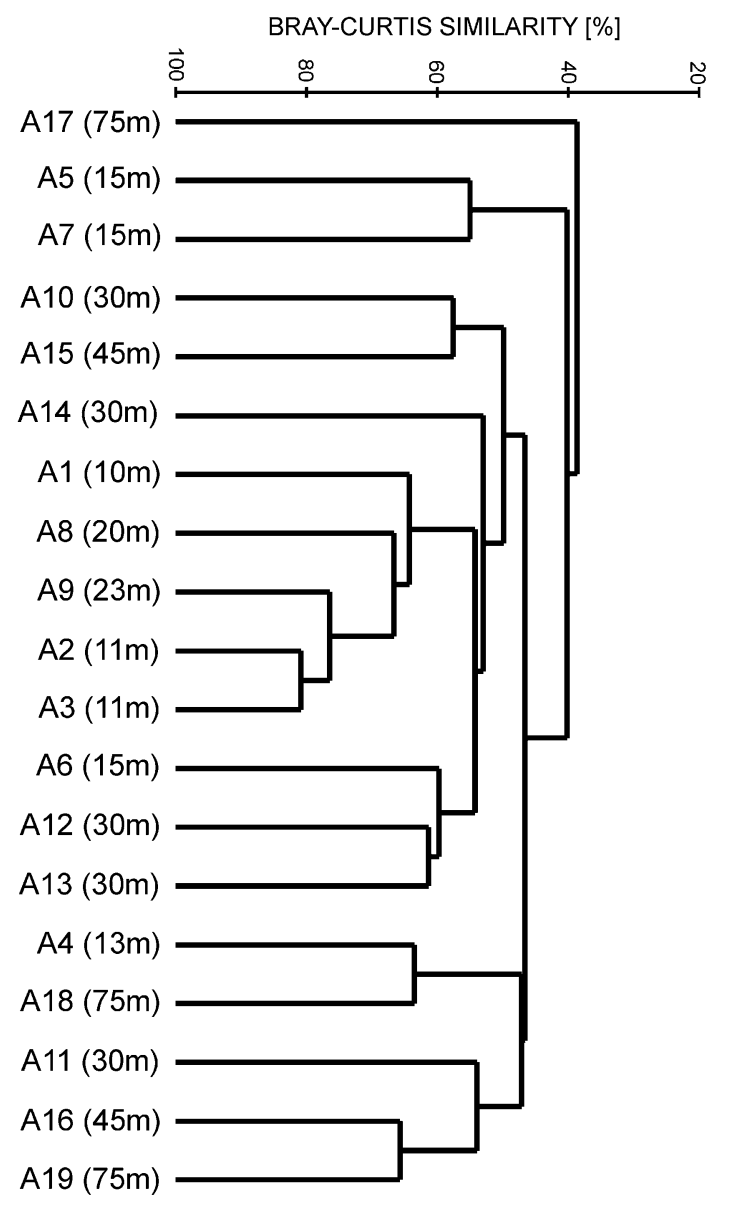

Fig. 3 Dendrogram of samples for the Bray-Curtis similarity, standardized, square root transformed data and group average grouping method

A high diversity of polychaete feeding guilds was observed. The holdfast fauna was strongly dominated by motile macrophagous herbivores but it also has a very high percentage of filter feeders. Polychaetes from ten feeding guilds were found and besides motile, non-jawed surface deposit feeders and sessile, tentaculate surface deposit feeders, all groups were quite numerous in this habitat (Fig. 4).

Regression analyses showed a correlation between the holdfast volume and densities of species and individuals. Both values decrease with increased holdfast volume. There was also a positive correlation between the number of individuals and the holdfast volume. There was no relationship between the number of species and holdfast volume, nor between density and depth (Fig. 5).

\section{Discussion}

There is a relatively small number of studies focused on the fauna of Antarctic and Subantarctic macroinvertebrates

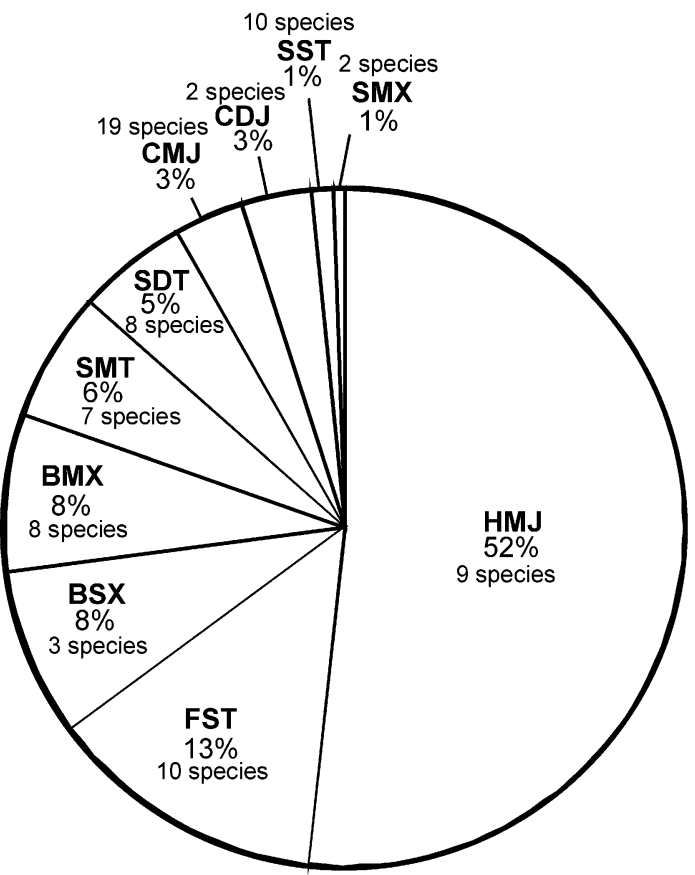

Fig. 4 Dominance structure of feeding guilds on $H$. grandifolius holdfasts according to Fauchald and Jumars (1979) classification. $C M J$ carnivore, motile, jawed; $H M J$ herbivore, motile, jawed; $B M X$ burrowing, motile, non-jawed; $C D J$ carnivore, discretely motile, jawed; $S M X$ surface deposit feeding, motile, non-jawed; $S D T$ surface deposit feeding, discretely motile, tentaculate; $S M T$ surface deposit feeding, motile, tentaculate; $B S X$ burrowing, sessile, non-jawed; $S S T$ surface deposit feeding, sessile, tentaculate; FST filter feeding, sessile, tentaculate

associated with holdfasts of various macroalgae. Arnaud (1974) found 34 species of polychaetes on 20 holdfasts of $H$. grandifolius from Adélie Land, a relatively small number compared to the results of the present study (78 species). The most frequent and dominant species on Adelie Land was Harmothoe sp. followed by Brania rhopalophora, Typosyllis brachychaeta and Kefersteinia fauveli. Another 30 species were found in very small numbers and mostly in single holdfasts. Also, Macrocystis pyrifera holdfasts from Kerguelen Islands were dominated by macrophagous, motile species (Arnaud 1974). Twentyseven species were found on 10 holdfasts. The most numerous and frequent species was Platynereis magalhaensis. Other dominant but less frequent species were Brania rhopalophora and Exogone heterosetosa. Rios et al. (2007) found 43 species of Polychaeta on Macrocystis pyrifera holdfasts from the Straits of Magellan. The most abundant species were Platynereis australis and Hermadion magalhaensis.

Both Arnaud (1974) and Rios et al. (2007) found some polychaetes that were present also on $H$. grandifolius holdfasts in Admiralty Bay (Table 3). The distribution of 

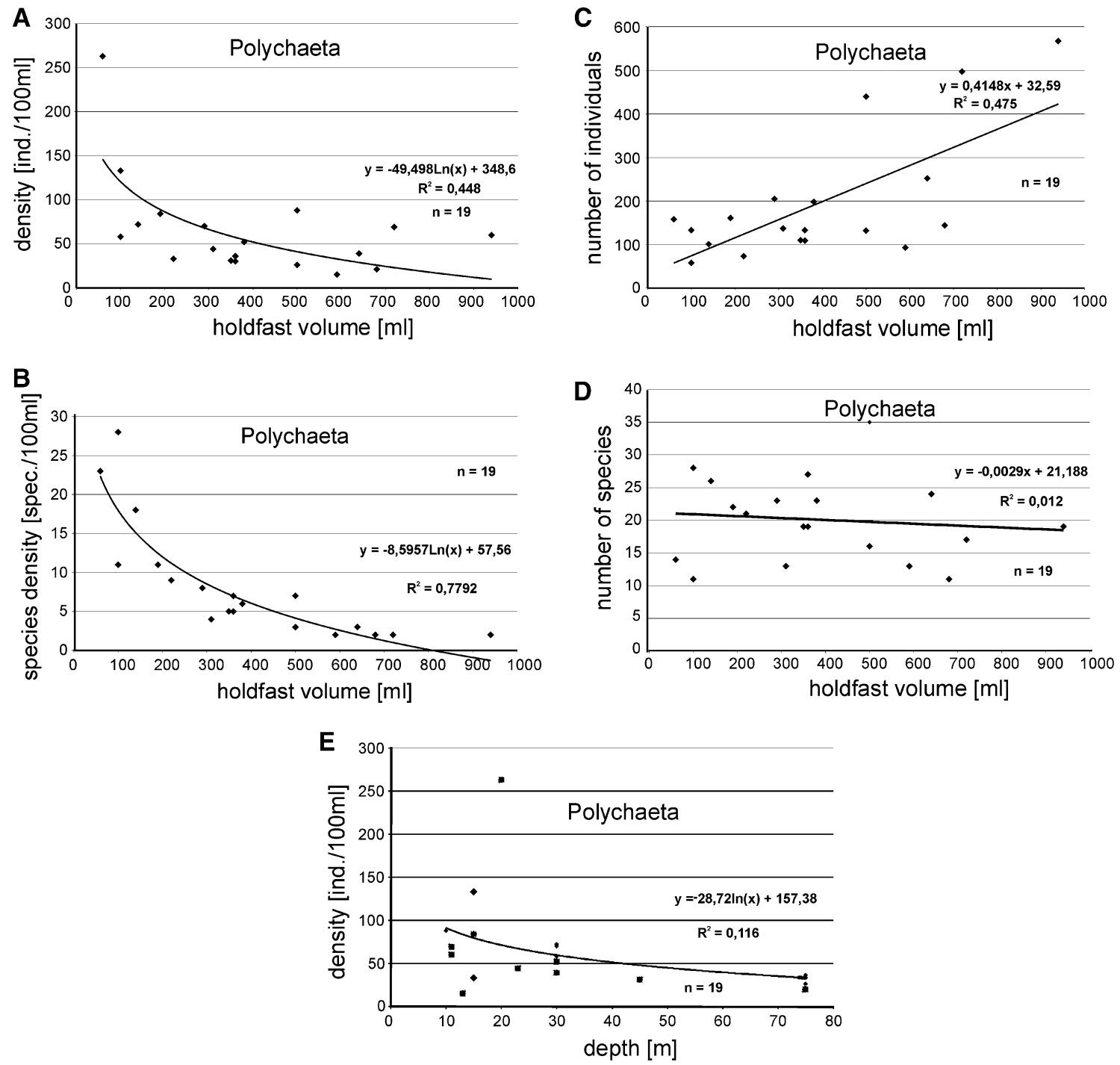

Fig. 5 Relationship between holdfast volume and: individuals density (a), species density (b), number of individuals (c) number of species (d) and relationship between depth and individuals density (e)

some of those species could be associated with drifting thalli and holdfasts of various algae. Smirnov (1982) found 30 polychaete species on floating holdfasts of $M$. pyrifera. The list includes species that were found also on H. grandifolius holdfasts in Admiralty Bay and on holdfasts from other Antarctic and Subantarctic locations (Table 3). Macrocystis pyrifera is considered as the main kelp vector of marine benthic faunal dispersion in the Southern Ocean, followed by Durvillea antarctica (Edgar 1987; Smith 2002). Polychaetes from the genera Exogone, Typosyllis and Nereis were able to drift on those holdfasts for almost 200 days (Edgar 1987). It was also found that some invertebrates, such as the bivalve Gaimardia trapesina, can drift for over $2000 \mathrm{~km}$ (Helmuth et al. 1994). However, some other species of macroalgae may also be an important element of this process. Floating thalli and holdfasts of H. grandifolius have been observed (Sicinski J., personal observation) but there are no data on their rafting fauna. The first step in understanding the dispersal processes of fauna associated with rafting holdfasts is the recognition of faunal communities associated with different macroalgae, from different Antarctic sites.

Most of the species that were found in $H$. grandifolius holdfasts were previously reported from Admiralty Bay. However, species that dominated on holdfasts, such as Brania rhopalophora and Neanthes kerguelensis, were found only in small numbers on soft-bottom habitats and were quite frequent only in shallow-water assemblages mostly in the phytal zone (Sicinski 1986; Sicinski and Janowska 1993; Bromberg et al. 2000; Sicinski 2004). It 
Table 3 List of species that were found on H. grandifolius holdfasts in Admiralty Bay and on holdfasts of various macroalgaes from other Antarctic and Subantarctic areas

\begin{tabular}{|c|c|c|c|c|c|c|}
\hline & $\begin{array}{l}\text { Himantothallus } \\
\text { grandifolius } \\
\text { Adélie Land } \\
\text { Arnaud (1974) }\end{array}$ & 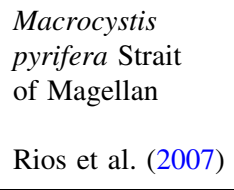 & $\begin{array}{l}\text { Macrocystis } \\
\text { pyrifera } \\
\text { Macquaire } \\
\text { Island } \\
\text { Edgar (1987) }\end{array}$ & $\begin{array}{l}\text { Macrocystis pyrifera } \\
\text { Antarctic and } \\
\text { Patagonian shelf } \\
\text { (floating holdfasts) } \\
\text { Smirnov (1982) }\end{array}$ & $\begin{array}{l}\text { Macrocystis pyrifera } \\
\text { Morbihan Bay, } \\
\text { Kerguelen Islands } \\
\text { Arnaud (1974) }\end{array}$ & $\begin{array}{l}\text { Durvillea antarctica } \\
\text { Morbihan Bay, } \\
\text { Kerguelen Islands } \\
\text { Arnaud (1974) }\end{array}$ \\
\hline Neanthes kerguelensis & & + & & + & & \\
\hline Brania rhopalophora & + & & + & + & + & \\
\hline Exogone heterosetosa & + & & + & + & + & \\
\hline Genetyllis polyphylla & & & & + & + & \\
\hline Eteone sculpta & & + & & + & & \\
\hline Eulalia picta & & & & + & & \\
\hline $\begin{array}{l}\text { Lumbrineris } \\
\text { magalhaensis }\end{array}$ & & + & & + & & \\
\hline $\begin{array}{c}\text { Leitoscoloplos } \\
\text { kerguelensis }\end{array}$ & & + & & & + & \\
\hline Scoloplos marginatus & + & & & + & & \\
\hline Spiopchanes tcherniai & + & & & & & \\
\hline Polycirrus insignis & + & & & + & & \\
\hline Thelepus cincinnatus & + & & & & & \\
\hline Oriopsis alata & & & & & + & + \\
\hline
\end{tabular}

seems that these species are strongly associated with holdfast and are present also on soft bottom in the Admiralty Bay phytal zone. On the other hand, some species like Oriopsis alata and Polycirrus insignis, previously not reported from Admiralty Bay (Sicinski 2000, 2004; Petti et al. 2006; Pabis and Sicinski 2010), were found in this habitat in relatively large numbers. Both species were already reported from holdfasts (Table 3) but only single individuals had been found (Arnaud 1974). Another three species: Euphrosine armadilloides, Sclerocheilus antarcticus and Oriopsis kocki were also recorded in Admiralty Bay for the first time.

The species composition and dominance structure of the holdfast polychaete community were completely different from Admiralty Bay soft-bottom communities that had been analysed in earlier studies, including those from a similar depth range (Sicinski and Janowska 1993; Sicinski 2004; Petti et al. 2006; Pabis and Sicinski 2010). Those differences were especially distinct on the sandy bottom of the central basin in the phytal zone (the same bottom area as for the holdfasts) (Sicinski and Janowska 1993). Only one species-Rhodine intermedia-was an important component of both communities. The most common and abundant infaunal species in Admiralty Bay are the Leitoscoloplos kerguelensis, Levinsenia gracilis, Ophelina syringopyge, Rhodine intermedia and Tharyx cincinnatus (Sicinski 1986, 2004; Petti et al. 2006). These species are also common and abundant, especially in the shallow areas, at other Antarctic sites such as Arthur Harbour (Lowry
1975), Signy Island (Hardy 1972), the Davis Sea (Gruzov et al. 1967), Anvers Island (Richardson and Hedgpeth 1977) and Terra Nova Bay (Gambi et al. 1994). Also, the most important epibenthic polychaete species found on soft bottoms in Admiralty Bay are completely different from those on holdfasts (Pabis and Sicinski 2010).

Another important feature is that the polychaete species richness and diversity at those sites were low in shallow areas. These patterns observed in Antarctic waters may be due to ice disturbance, which is stronger in the shallow water (Smale 2008). However, there was a clear difference in the species richness between the holdfast assemblages and soft-bottom infaunal communities in Admiralty Bay. On the soft bottom in the phytal zone of Admiralty Bay central basin (4-30 m), only 25 species were found (Sicinski and Janowska 1993). In most other infaunal polychaete assemblages distinguished in Admiralty Bay, the number of species was much lower, varying from 9 to 35. Only in two assemblages it was higher: fifty-six species were found in the "Tharyx cincinnatus assemblage" (Ezcurra Inlet at 45-165 m), while eighty-one were found in the "Tauberia gracilis assemblage" (Central basin at $35-150 \mathrm{~m}$ ), which is associated with heterogenous sediments that can also be treated as a comparatively more complex habitat (Sicinski 2004). It is also notable that the total number of polychaete species found in all earlier studies from Admiralty Bay, in different habitats, is 162 (in samples taken with different sampling gears-Van Veen grab, Kangas sampler, trawls, dredges, epibenthic sledge, 
various corers) while in the holdfast habitat alone nearly 80 species were found. This is even more striking when the scale of the holdfast sampling area is considered in relation to surface of the whole bay (Fig. 2).

It has been pointed out that depth of 35-40 m delimits a significant zoocoenological boundary for benthos in the central part of the Bay (Jazdzewski et al. 1986; Jazdzewski and Sicinski 1993). Similar observations have been made in Martel Inlet with 20-25 m depth as a limit associated with stronger ice disturbance in the shallows (Nonato et al. 2000). This boundary seems to be absent in the H. grandifolius holdfast polychaete community. Holdfasts constituted one group in the cluster analysis. No partitioning related to depth was observed for holdfasts compared with earlier studies on soft-bottom faunas. Holdfasts provide a shelter for invertebrates especially in shallow water, which may be why there was no depth-partitioning of the holdfast polychaete assemblage. Holdfasts may also be partially filled with sediment, providing a habitat for infauna. This ability for accumulation of sediment and detritus is a result of the complexity of holdfast labyrinths and can increase the species richness of fauna associated with this habitat (Smith 1996). It was observed that H. grandifolius can grow in the ice-disturbed areas. It grows on relatively small stones and can be pushed aside and thus avoids destruction (Klöser et al. 1994). Holdfasts in polar regions can provide a shelter and are probably less susceptible to destruction than other parts of the kelp (WlodarskaKowalczuk et al. 2009). It has been observed that diversity on holdfasts can be higher when kelp is exposed to strong mechanical stresses such as wave action (Schultze et al. 1990).

In a study from temperate Australia, depth was an important factor influencing the distribution and composition of kelp-associated fauna (Coleman et al. 2007). However, most of the Antarctic polychaetes are eurybathic so factors other than depth (habitat type, habitat complexity, organic matter content, sediment type, iceberg scour) are the most important influences on the vertical distribution. While depth-partitioning has been observed in soft-bottom communities, no partitioning was found in the specific habitat of holdfasts (not dependent on the sediment type and protected from ice disturbance) and with a eurybathic group of invertebrates as the subject of study. Coleman et al. (2007) stressed also that contrary patterns may occur as a result of biogeographic variation between studies.

It has been pointed out that complex habitats are characterized by many rare species and few dominants (Hughes 1984; Morgado and Tanaka 2001), including on kelp holdfasts (Rios et al. 2007). This may be a result of recruitment patterns (Hughes 1984). Holdfasts can be treated as islands. Invertebrates can immigrate to or emigrate from these islands. They may also demonstrate the founder effect, as has already observed for peracarid crustaceans (Thiel and Vasquez 2000). Some species can be very abundant in some holdfasts and absent in others. It was further suggested for peracarids that reproduction rates may sometimes exceed the rate of migration between the holdfasts (Thiel and Vasquez 2000). A similar situation was observed for polychaetes on $H$. grandifolius holdfasts in Admiralty Bay. Some species like Paralaeospira antarctica, Tharyx epitoca, Tharyx cincinnatus, Genetyllis polyphylla or Lumbriclymenella robusta show relatively high dominance and low or very low frequency.

Migrations and the island character of holdfasts might also explain why no correlation was found between the number of species and holdfast volume. Some holdfasts may receive only single colonizers while other may completely lack some species, and this accidental process is not related to factors such as depth or holdfast volume. This process is also similar to island colonization. For the animals that colonize a holdfast, it may be more favourable to remain on the "island" than to move to another one (Thiel and Vasquez 2000). However, on Lessonia trabeculata Villouta et Santelices, Lessonia nigrescens Bory de SaintVincent and Macrocystis integrifolia Bory de Saint-Vincent holdfasts in Chile, the number of invertebrate species was strongly positively correlated with increasing holdfast volume (Thiel and Vasquez 2000). The same situation was observed on Macrocystis pyrifera holdfasts from southern Chile (Ojeda and Santelices 1984). The number of individuals in this study increased with increasing holdfast volume (Fig. 5), confirming earlier observations of this pattern (Ojeda and Santelices 1984; Thiel and Vasquez 2000; Anderson et al. 2005). Equally, different and even contrary results can be found depending on the taxonomic group (Anderson et al. 2005).

A further feature of the polychaete community associated with holdfasts in Admiralty Bay is the decrease in the density of individuals and of species with increasing holdfast volume. This may result from recruitment and colonization processes. Holdfast colonization rate is probably high in its initial stage and decreases with time. It was observed that artificial kelp holdfasts are colonized by the typical fauna within only few days (Norderhaug et al. 2002). Small holdfasts can be effectively colonized in a relatively short time. Thus, density of polychaetes may be higher in smaller holdfasts than in larger ones. However, the number of individuals is higher in the larger holdfasts (Fig. 5). Probably, their immigration or/and reproduction cannot compensate for the larger holdfast volume. In consequence, the density remains lower than in smaller holdfasts.

It was observed that the migration between holdfasts may be restricted, and most of the species that colonized the holdfast do not migrate to another one (Thiel and 
Vasquez 2000). If the number of species inhabiting holdfast is not related to the holdfast volume or depth, then the species number on each holdfast may be more or less similar. That would explain why the species density (number of species/100 ml) is negatively correlated to holdfast volume.

A difference in functional-group composition was observed between the polychaete fauna associated with holdfast and that associated with soft bottoms. The presence of microphagous detritus feeders: burrowers and surface deposit feeders is typical for the soft bottom (Gallardo et al. 1988; Gambi and Busotti 1999; San Martin et al. 2000; Sicinski 2004). A dominance of macrophagous motile polychaetes, herbivores or predators had already been observed on macroalgal holdfasts and thalli in the Antarctic as well as in other regions of the world (Arnaud 1974; Rios et al. 2007; Fraschetti et al. 2002). In the present study, a high number of filter feeders were also observed. Holdfasts are good substratum for attachment for these polychaetes. On various algae, Antoniadou and Chintiroglou (2006) found carnivorous and herbivorous species together with filter feeders as dominating groups. The important feature is that, on the soft bottom, simplification of functional-group composition was observed with a high dominance of microphagous species, mostly from four guilds of burrowing (BMX, BSX) and motile surface deposit feeding (SMT or SMX) polychaetes (Sicinski 2004). It was especially apparent in shallow areas, while on holdfasts, despite the high dominance of motile herbivores, almost all other feeding guilds were represented in significant proportions. This constitution could be directly and indirectly due to the complexity of this habitat, including the ability for accumulation of sediment in the branches of holdfasts. The number and diversity of ways of exploiting environmental resources is believed to be higher in more complex habitats (Tews et al. 2004).

\section{Conclusions}

1. The number of species on $H$. grandifolius holdfasts is much higher than that in infaunal shallow sublittoral polychaete communities. It is probable that the complex structure of holdfasts provides good shelter and protection from disturbance, especially in shallowwater bottom areas.

2. The polychaete community associated with $H$. grandifolius holdfasts is uniform in terms of its composition of dominant species and dominance structure over the whole depth range investigated.

3. The holdfast polychaete community differs strongly from previously studied polychaete communities associated with soft bottoms, mainly in terms of species composition and feeding-guild structure. It is dominated by jawed motile herbivores and sessile tentaculate filter feeders.

4. The diversity of polychaete feeding guilds in the holdfast community was higher than that found in softbottom communities.

Acknowledgments We are grateful to Dr M. Grabowski for his comments on the manuscript. We also want to thank Dr Monica Petti and two anonymous reviewers for their advice and criticism that helped us to improve this article. Thanks are also due to Dr Roger Bamber for language correction and polishing the final version of the manuscript. The study was supported by a grant from the Polish Ministry of Science and Higher Education NO 51/N-IPY/2007/0 as well as the Census of Antarctic Marine Life project.

Open Access This article is distributed under the terms of the Creative Commons Attribution Noncommercial License which permits any noncommercial use, distribution, and reproduction in any medium, provided the original author(s) and source are credited.

\section{References}

Adami ML, Gordillo S (1999) Structure and dynamics of the biota associated with Macrocystis pyrifera (Phaeophyta) from the Beagle Channel, Tierra del Fuego. Sci Mar 63:183-191

Almany GR (2004) Does increased habitat complexity reduce predation and competition in coral reef fish assemblages? OIKOS 106:275-284

Anderson MJ, Diebel CE, Blom WM, Landers TJ (2005) Consistency and variation in kelp holdfast assemblages: Spatial patterns of biodiversity for the major phyla at different taxonomic resolutions. J Exp Mar Biol Ecol 320:35-56

Antoniadou C, Chintiroglou C (2006) Trophic relationships of polychaetes associated with different algal growth forms. Helgol Mar Res 60:39-49

Arnaud PM (1974) Contribution a la bionomie marine benthique des regions antarctiques et subantarctiques. Tethys 6:465-656

Braun M, Grossmann H (2002) Glacial changes in the areas of Admiralty Bay and Potter Cove, King George Island, maritime Antarctica. In: Beyer L, Bolter M (eds) Geoecology of the antarctic ice-free coastal landscapes. Springer, Berlin, pp 75-90

Bromberg S, Nonato EF, Corbisier TN, Petti MAV (2000) Polychaete distribution in the near-shore zone of Martel Inlet, Admiralty Bay (King George Island, Antarctica). Bull Mar Sci 6:175-188

Clarke KR, Warwick RM (1994) Change in marine communities: an approach to statistical analysis and interpretation. Natural Environment Research Council, Plymouth

Coleman MA, Vytopil E, Goodsell PJ, Gillanders BM, Connell SD (2007) Diversity and depth related patterns of mobile invertebrates associated with kelp forests. Mar Fresh Res 58:589-595

Corkum LD, Cronin DJ (2004) Habitat complexity reduces aggression and enhances consumption in crayfish. J Ethol 22:23-27

Dunton KH, Reimnitz E, Schonberg S (1982) An Arctic community in the Alaskan Beaufort Sea. Arctic 35:465-484

Edgar GJ (1987) Dispersal of faunal and floral propagules associated with drifting Macrocystis pyrifera plants. Mar Biol 95:599-610

Eriksson BK, Rubach A, Hillebrand H (2006) Biotic habitat complexity controls species diversity and nutrient effects on net biomass production. Ecology 87:246-254 
Fauchald C, Jumars PA (1979) The diet of worms: a study of polychaete feeding guilds. Oceanogr Mar Biol Annu Rev 17:193-284

Fraschetti S, Giangrande A, Terlizzi A, Miglietta MP, DellaTomassa L, Boero F (2002) Spatio-temporal variation of hydroids and polychaetes associated with Cystoseira amentacea (Fucales: Phaeophyceae). Mar Biol 140:949-957

Furmanczyk K, Zielinski K (1982) Distribution of macroalgae groupings in shallow waters of Admiralty Bay (King George Island, South Shetland Islands, Antarctic), plotted with the help of air photographs analysis. Pol Polar Res 3:41-47

Gallardo VA, Medrano SA, Carrasco FD (1988) Taxonomic composition of the sublittoral soft-bottom Polychaeta of Chile Bay (Greenwich Island, South Shetland Islands, Antarctica). Ser Cien INACH 37:49-67

Gambi MC, Busotti S (1999) Composition, abundance and stratification of soft-bottom macrobenthos from selected areas of the Ross Sea shelf (Antarctica). Polar Biol 21:347-354

Gambi MC, Lorenti M, Russo GF, Scipione MB (1994) Benthic associations of the shallow hard bottoms off Terra Nova Bay, Ross Sea: zonation, biomass and population structure. Antarct Sci 6:449-462

Gray JS (2001) Antarctic marine benthic biodiversity in a world-wide latitudinal context. Polar Biol 24:633-641

Gruzov EN, Propp MV, Puskin AE (1967) Biologicheskiye soobshchestva pribrezhnych rayonov morya Davisa [Biological associations of coastal areas of the Davis Sea, based on the observation of divers.]. Inf Bjull Sov Ant Eksp 65:124-141

Hardy P (1972) Biomass estimates for some shallow-water infaunal communities at Signy Island, South Orkney Islands. Brit Antarct Surv Bull 31:93-106

Helmuth B, Veit RR, Holberton R (1994) Long-distance dispersal of subantarctic brooding bivalve (Gaimardia trapesina) by kelprafting. Mar Biol 120:421-426

Hereu B, Zabala M, Linares C, Sala E (2005) The effects of predator abundance and habitat structural complexity on survival of juvenile sea urchins. Mar Biol 146:293-299

Hughes RG (1984) A model of the structure and dynamics of benthic marine invertebrate communities. Mar Ecol Prog Ser 15:1-11

Jazdzewski K, Sicinski J (1993) Zoobenthos. General remarks. In: Rakusa-Suszczewski S (ed) The maritime coastal ecosystem of admiralty bay. Department of Antarctic Biology Polish Academy of Sciences, Warsaw, pp 83-95

Jazdzewski K, Jurasz W, Kittel W, Presler E, Presler P, Sicinski J (1986) Abundance and biomass estimates of the benthic fauna in Admiralty Bay, King George Island, South Shetland Islands. Polar Biol 6:5-16

Klöser H, Mercuri G, Laturnus F, Quartino ML, Wiencke C (1994) On the competitive balance of macroalgae at Potter Cove (King George Island, South Shetlands). Polar Biol 14:11-16

Koehl MAR (1999) Ecological biomechanics of benthic organisms: life history, mechanical design and temporal patterns of mechanical stress. J Exp Biol 202:3469-3476

Kohn AJ, Leviten PJ (1976) Effect of habitat complexity on population density and species richness in tropical intertidal predatory gastropod assemblages. Oecologia 25:199-210

Le Hir MI, Hily C (2005) Macrofaunal diversity and habitat structure in intertidal boulder fields. Biodiv Cons 14:233-250

Lowry JK (1975) Soft bottom macrobenthic community of Arthur Harbor, Antarctica. In: Pawson DL (ed) Antarctic research series 23, biology of the antarctic seas V. American Geophysical Union, Washington, DC, pp 1-19

Morgado EH, Tanaka MO (2001) The makrofauna associated with the bryozoan Schizoporella errata (Walters) in southeastern Brazil. Sci Mar 65:173-181
Nonato EF, Brito TAS, De Paiva PC, Petti MAV, Corbisier TN (2000) Benthic megafauna of the nearshore zone of Martel Inlet (King George Island, South Shetland Islands, Antarctica): depth zonation and underwater observations. Polar Biol 23:580-588

Norderhaug KM, Christie H, Rinde E (2002) Colonisation of kelp imitations by epiphyte and holdfast fauna; a study of mobility patterns. Mar Biol 141:965-973

Ojeda FP, Santelices B (1984) Invertebrate communities in holdfasts of the kelp Macrocystis pyrifera from southern Chile. Mar Ecol Prog Ser 16:65-73

Oliveira EC, Absher TM, Pellizzari FM, Oliveira MC (2009) The seeweed flora of Admiralty Bay, King George Island, Antarctic. Polar Biol 32:1639-1647

Pabis K, Sicinski J (2010) Distribution and diversity of polychaetes collected by trawling in Admiralty Bay-an Antarctic glacial fiord. Polar Biol 33:141-151

Petti MAV, Nonato EF, Skowronski RSP, Corbisier TN (2006) Bathymetric distribution of the meiofaunal polychaetes in the nearshore zone of Martel Inlet, King George Island, Antarctica. Antarct Sci 18:163-170

Richardson MD, Hedgpeth JW (1977) Antarctic soft-bottom, macrobenthic community adaptation to a cold, stable, highly productive, glacially affected environment. In: Llano GA (ed) Adaptation within Antarctic ecosystems. Gulf, Houston, pp 181-196

Rios C, Arntz WE, Gerdes D, Mutschke E, Montiel A (2007) Spatial and temporal variability of the benthic assemblages associated to the holdfasts of the kelp Macrocystis pyrifera in the Straits of Magellan, Chile. Polar Biol 31:89-100

San Martin G, Parapar J, Garcia FJ, Redondo MS (2000) Quantitative analysis of soft bottoms infaunal macrobenthic polychaetes from South Shetland Islands (Antarctica). Bull Mar Sci 67:83-102

Schultze K, Janke K, Krub A, Weidemann W (1990) The macrofauna and macroflora associated with Laminaria digitata and L. hyperborea at the island of Helgoland (German Bight, North Sea). Helgol Wiss Meeresunters 44:39-51

Sicinski J (1986) Benthic assemblages of Polychaeta in chosen regions of the Admiralty Bay (King George Island, South Shetland Islands). Pol Polar Res 7:63-78

Sicinski J (2000) Polychaeta (Annelida) of Admiralty Bay: species richness, diversity, and abundance. Pol Polar Res 21:153-169

Sicinski J (2004) Polychaetes of Antarctic Sublittoral in the proglacial zone (King George Island, South Shetland Islands). Pol Polar Res 25:67-96

Sicinski J, Janowska E (1993) Polychaetes of the shallow sublittoral of Admiralty Bay, King George Island, South Shetland Islands. Antarct Sci 5:161-167

Smale DA (2008) Continuous benthic community change along a depth gradient in Antarctic shallows: evidence of patchiness but not zonation. Polar Biol 31:189-198

Smirnov IS (1982) Fauna plavajuščich rizoidov makrofitov iz subantarktiki i rajona patagonskogo šelfa. [Fauna of floating kelp rhizoids from the Subantarctic and Patagonic shelf.]. Issl Fauny Mor 28:108-109

Smith SDA (1996) The macrofaunal community of Ecklonia radiata holdfasts: Variation associated with sediment regime, sponge cover and depth. Aust J Ecol 21:144-153

Smith SDA (2000) Evaluating stress in rocky shore and shallow reef habitats using the macrofauna of kelp holdfasts. J Aquat Ecosyst Stress and Recovery 7:259-272

Smith SDA (2002) Kelp rafts in the Southern Ocean. Glob Ecol Biogeogr 11:67-69

Smith SDA, Simpson RD (1998) Recovery of benthic communities at Macquarie Island (sub-Antarctic) following a small oil spill. Mar Biol 131:567-581 
Smith SDA, Simpson RD (2002) Spatial variation in the community structure of intertidal habitats at Macquarie Island (sub-Antarctic). Antarct Sci 14:374-384

Steneck RS, Graham MH, Bourque BJ, Corbett D, Erlandson JM, Estes JA, Tegner MJ (2002) Kelp forests ecosystems: biodiversity, stability, resilience and future. Environ Conserv 29:436-459

Tews J, Brose U, Grimm V, Tielborger K, Wichmann MC, Schwager M, Jeltsch F (2004) Animal species diversity driven by habitat heterogeneity/diversity: the importance of keystones structures. J Biogeogr 31:79-92
Thiel M, Vasquez JA (2000) Are kelp holdfasts islands on the oceans floor?-indications for temporarily closed aggregations of peracarid crustaceans. Hydrobiologia 440:45-54

Wlodarska-Kowalczuk M, Kuklinski P, Ronowicz M, Legezynska J, Gromisz S (2009) Assessing species richness of macrofauna associated with macroalgae In Arctic kelp forests (Hornsund, Svalbard). Polar Biol. doi: 10.1007/s00300-009-0590-9

Zielinski K (1990) Bottom macroalgae of the Admiralty Bay (King George Island, South Shetlands, Antarctica). Pol Polar Res 11:95-131 